\title{
Estimating aquatic invertebrate diversity in the southern Alps using data from Biodiversity Days
}

\author{
Georg H. Niedrist, ${ }^{1 *}$ Birgit Lösch, ${ }^{2}$ Magdalena Nagler, ${ }^{3}$ Hannes Rauch,,${ }^{2}$ Samuel Vorhauser, ${ }^{2}$ Alberto Scotti,${ }^{4}$ \\ Roberta Bottarin, ${ }^{4}$ Renate Alber ${ }^{2}$ \\ ${ }^{1}$ Department of Ecology, River and Conservation Research, University of Innsbruck, Austria; ${ }^{2}$ Biological Laboratory, Agency for \\ Environment and Climate Protection of the Autonomous Province Bolzano South Tyrol, Laives, Italy; ${ }^{3}$ Institute of Microbiology, \\ University of Innsbruck, Austria; ${ }^{4}$ Eurac Research, Institute for Alpine Environment, Bolzano, Italy
}

\begin{abstract}
High biodiversity is a prerequisite for the integrity, stability, and functioning of global aquatic ecosystems, but it is currently subject to anthropogenic threats. Small freshwater bodies with high habitat diversity are essential to sustain regional biodiversity, but species inventory and biodiversity are largely overlooked, especially in mountainous regions. In the Italian Alps, obligate assessments of freshwater biota (e.g., for the European water framework directive, WFD) are usually done in larger rivers or lakes only, which is why many taxa from small freshwater habitats might have been overlooked so far. Here we summarize and discuss the efforts to record aquatic invertebrates within the framework of so-called "Biodiversity Days", organized since 2001 at 13 different sites located across the North Italian province of South Tyrol. These events with voluntary participation of scientists and naturalists from universities and environmental agencies led to the detection of 334 benthic invertebrate taxa in streams and lakes (mostly at species or genus level), whereby higher taxa richness was found in streams. The overall hierarchy of species numbers within invertebrate orders or families corresponded to that of other Alpine regions (groups richest in taxa were Chironomidae and Trichoptera) and these Biodiversity Days contributed to biodiversity research of that region in detecting 167 additional taxa. Besides analyzing yearly gains in the regional taxa inventory, we predict that future surveys will lead to new discoveries of aquatic taxa for that province (i.e., current modeling estimates a regional inventory of more than 600 taxa). However, specific surveys in hitherto unconsidered habitats, such as morphologically modified or urban waters, might reveal even more taxa than currently estimated. Besides characterizing the invertebrate fauna of this region and providing a first reference list for future monitoring projects in the same region, this work demonstrates that such Biodiversity Days can contribute to biodiversity research.
\end{abstract}

\section{INTRODUCTION}

Biodiversity is an important feature of ecological communities, describing interactive systems of species co-occurring in natural ecosystems (Noss, 1990). As co-occurring species are supposed to comply different

Corresponding author: Georg.Niedrist@uibk.ac.at ORCID: 0000-0002-2852-4661

Key words: Freshwater; monitoring; benthos; Alpine; streams; South Tyrol.

Conflict of interest: The authors declare no conflict of interest.

Edited by: John P. Smol, Paleoecological Environmental Assessment and Research Lab, Queen's University, Kingston, Canada.

Received: 11 December 2020.

Accepted: 26 April 2021

This work is licensed under a Creative Commons Attribution NonCommercial 4.0 License (CC BY-NC 4.0).

${ }^{\circ}$ Copyright: the Author(s), 2021

Licensee PAGEPress, Italy

J. Limnol., 2021; 80(2):1999

DOI: 10.4081/jlimnol.2021.1999 functions and to fit into distinct ecological niches with varying niche widths (Hutchinson, 1957), the magnitude of species richness allows an estimation of the functional diversity and redundancy within a community and stability in a certain habitat (Cardinale, 2011). Recent findings demonstrate that the diversity of ecosystems, species and biological traits are decreasing at an alarming rate due to human actions (Cardinale et al., 2012), possibly leading to the sixth mass extinction in earth's history (Ceballos et al., 2015), with particularly high rates of biodiversity loss in freshwaters (Sala et al., 2000). Especially small freshwater bodies (e.g., low order streams, ponds), which provide patches of diverse habitats, are known to disproportionally contribute to regional species in contrast to larger lakes or rivers (Davies et al., 2008) and being important for freshwater biodiversity at landscape scale (Biggs et al., 2017). Although locally non-native species might expand their range and partly compensate lost ecosystem functions (McKinney and Lockwood, 1999), the observed losses will degrade ecological interactions (Valiente-Banuet et al., 2015), and change the functionality, goods and services of the ecosystems (Naeem et al., 1994; Olden et al., 2004; Cardinale, 2011; Duncan et al., 2015). Further, species losses and the overall homogenization of freshwater communities might reduce the stability, resistance and resilience of the communities (Petchey, 2003) to changing habitat conditions (e.g., climate 
change, invasive alien species) or extreme events such as floods or pollution (Peterson et al., 1998; Elmqvist et al., 2003; Oliver et al., 2015).

The current species losses lead to a frequent use of the term biodiversity in scientific, political, and media context, but the visualizations of biodiversity for the public focuses mainly on popular plants and animals, stimulating the public awareness through catchy headlines (Jacobsen et al., 2008). The biological diversity, however, ranging from smaller (e.g., plant rhizosphere) to broader scales (ecosystem-level) is less known to the public, despite playing an essential role in the functioning of ecosystems and the well-being of human societies (Duncan et al., 2015). Policy makers often ignore small water bodies outside protected areas and economical spheres, resulting in lacking surveys of distinct types of water in certain areas and partly unknown identities of the overall species inventory in many regions (Strayer and Dudgeon, 2010). While specific habitats are well studied (e.g., glacial or high-altitude rivers; Rossaro et al., 2006; Niedrist et al., 2017; Lencioni, 2018; Scotti et al., 2019a), estimates of regional diversity are not available for the Southern (European) Alps, which limits overall trend observations and stability predictions.

Habitat conditions in Alpine rivers are mostly affected by hydromorphological degradations (Muhar et al., 2019), but also by climatic changes, as rapid contemporary warming with a mean rate of $2.5^{\circ} \mathrm{C}$ per decade has already been observed in Alpine headwaters (Niedrist and Füreder, 2021). Since high species diversity and functional redundancy has been found essential to mitigate warming effects on ecosystem functioning (García et al., 2018), monitoring and conserving native aquatic biodiversity and dominant taxa is key for maintaining the integrity of these ecosystems. Though freshwaters in the Alps are generally referred to as pristine hydrosystems, their ecology and species richness have been and will be affected by different anthropogenic pressures (Giulivo et al., 2019; Niedrist et al., 2021) combined with the effects of climate change (Braun et al., 2000; Füreder, 2012; Brown et al., 2015).

Alpine freshwater invertebrates (among others, insect larvae, crustaceans, ringed worms, or mollusks) colonize aquatic (micro-) habitats and can be seen as the first consumers in aquatic food webs (Niedrist and Füreder, 2017), but also important decomposers and recycler of microbes, algae, macrophytes, or detritus (Wallace and Webster, 1996) and thus as suppliers of food for other invertebrates and later for aquatic and terrestrial vertebrates (fish, birds, etc.; Prather et al., 2013, Macadam and Stockan, 2015). However, as freshwater invertebrates mostly live hidden at the bottom of the water body, even in remote areas or in habitats that are not examined, their overall diversity is still unknown for many geographic regions (Abell et al.,
2008; Strayer and Dudgeon, 2010; Collen et al., 2014), and the southern Alps are such an example (despite the regular site-specific surveys mandatory for the water framework directive; Haase et al., 2013).

Biodiversity Days are action days gathering scientists and naturalists from universities, environmental agencies and other institutions with the aim to identify as many different plants, animals, fungi, etc. as possible within a specific area, thus, to estimate on a single day the maximum number of species present in that certain region. This movement, started and initiated in 1999 by the GEO-magazine (Hamburg, Germany), has been reproduced every year and in several regions, leading to a broad network of Biodiversity Days in Central Europe. The main aims are to identify species assemblages in different habitats and thereby make an inventory of biological diversity, as well as raising awareness to the public. Interested participants assist experts and can thus actively contribute to biodiversity research, which generally raises the social awareness and understanding of regional biodiversity and sensitizes people for conservation issues (Kobori et al., 2016). Moreover, such cost-efficient records of biological diversity, done by many volunteers, allow multi-year assessments of certain ecosystems (in this case water bodies) in many places of a region (Miller-Rushing et al., 2012). So far, it is unclear, however, if, how and to what extent such actions can contribute to the estimation of the overall aquatic biodiversity of a region.

In South Tyrol, a province in northern Italy, the Biodiversity Days started in 2001 and studied several places (and the water bodies therein) on thirteen occasions over the course of 17 years (2001-2017). The present work aims to characterize the invertebrate inventory of the studied water bodies distributed over that region and to discuss the benefit of these action days with regard to the record of benthic invertebrate taxa in South-Tyrolean freshwater bodies. The resulting taxa list can serve as reference for future monitoring efforts.

\section{METHODS}

\section{Study areas and sampling}

The Days of Biodiversity considered in this study took place within South Tyrol, an autonomous province in the northern Italian region Trentino-Alto Adige with an area of $7400 \mathrm{~km}^{2}$. Aquatic entomologists specialized in different taxonomic groups met on thirteen occasions in June from 2001 until 2017 (i.e., 2001, 2002, 2004, 2007, 2008, 2009, 2011, 2012, 2013, 2014, 2015, 2016, 2017; Lösch, 2008, 2013, 2014; Lösch and Alber, 2009; Lösch et al., 2012, 2016; Alber et al., 2015, Niedrist et al. 2017), surveying the aquatic habitats located within randomly selected areas of similar geographical extent within that 
province at every Biodiversity Day (Fig. 1, Tab. S1). These aquatic sites were located within larger areas, in which also the biodiversity of terrestrial taxonomic groups has been recorded. Qualitative multi-habitat sampling, always led by professional but voluntarily participating entomologists, were taken from standing and/or running water bodies present in each of these areas. The standing habitat at S4 (Tab. S1) was surveyed as part of another project, hence the number of sampled microhabitats exceeded that of Biodiversity Day assessments. Macroinvertebrates were brushed and scraped from the surfaces of stream-bed substrates (or whirled up by stirring sediments in lakes) and captured using a kick-net (mesh size of $500 \mu \mathrm{m}$ ). Larger substrates (e.g., large wood debris) were rinsed manually. An attempt was made to sample all representative microhabitats of the examined waters (adapted from Ofenböck et al., 2010; U.S. Environmental Protection Agency, 2018) to include as many species as possible. Such a procedure led to the innumerable observations of same species, but also ensured the coverage of rare animals. Since we aimed to qualitatively sample all possible habitats, each sampling might represent most of the present taxa (except the survey in 2007) - independent of the involved researchers (the number of participants ranged between 1 and 4). The sampling methods itself were the same on all sampling occasions. Invertebrates were manually separated from debris in the field, stored in $75 \%$ ethanol and identified to the lowest taxonomic level by experts for the respective groups (order or families) in different laboratories using published keys (Waringer and Graf, 1997; Janecek, 1998; Lubini et al., 2012; Bauernfeind and Humpesch, 2001; Zwick, 2004; Rossaro and Lencioni, 2015). While most animals were determined on species and genus levels, a few taxa remained at family-level. However, such individuals only counted as independent taxon if no genus of this family has been determined (Tab. S2).

\section{Analysis}

We related community patterns to the habitat variables (habitat type, altitude, geographical position) by performing an RDA (redundancy analysis) with vegan (Oksanen

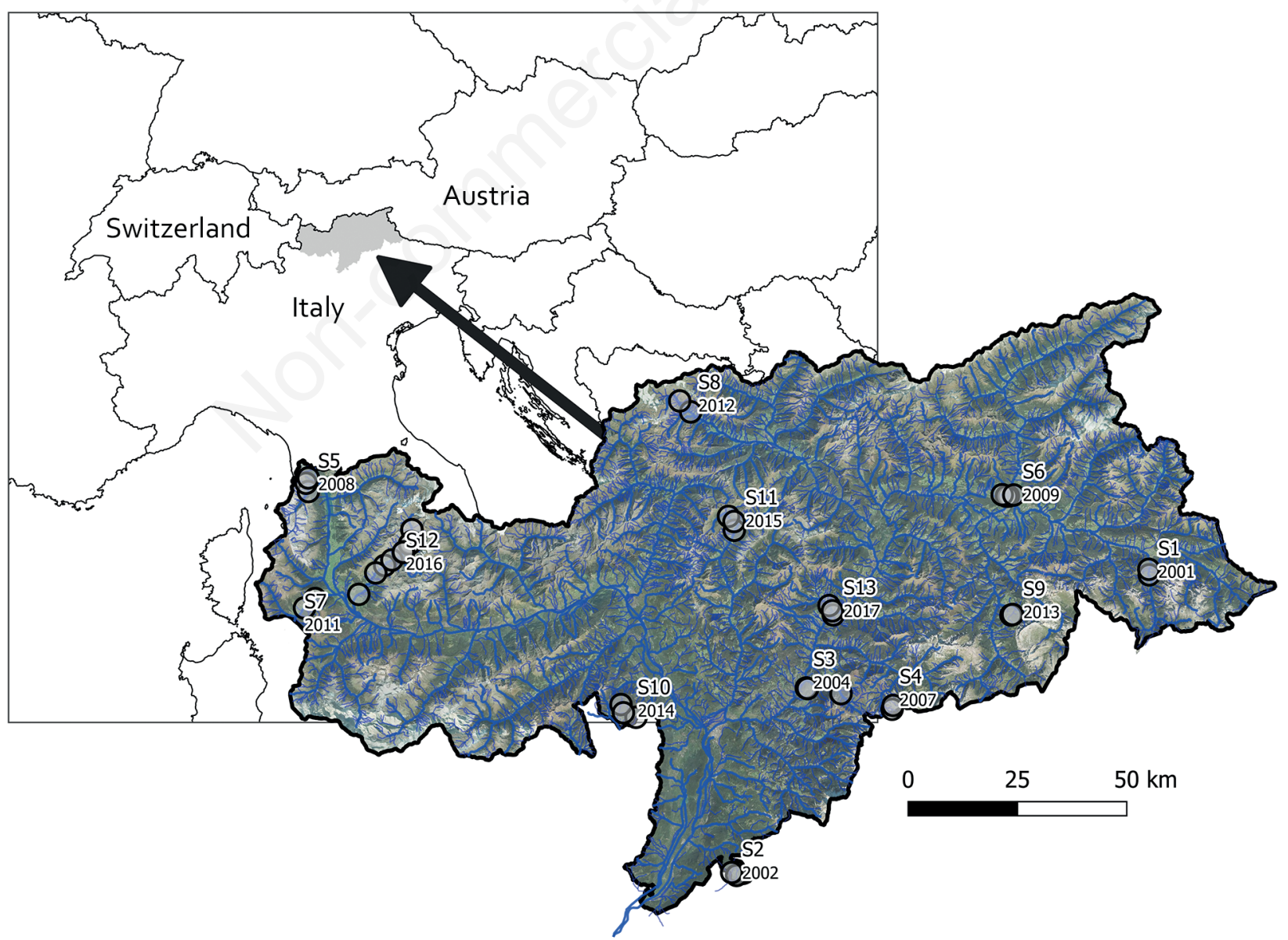

Fig. 1. Map of the region South Tyrol (Italy) and the locations of the Biodiversity Days in the years 2001 to 2017. 
et al., 2017). For each habitat type we draw $95 \%$ confidence intervals using the function ordiellipse. The difference of communities (community composition) between lentic and lotic habitats (habitat type) and the influence of environmental conditions were quantified via PERMANOVA (9999 permutations) by considering basic habitat variables [habitat type (lentic vs lotic), altitude, geographical position]. Absolute and relative contributions of invertebrate families and orders to the sampled communities were calculated for each year. Newly identified taxa were added yearly to the existing taxa pool of the respective invertebrate groups and graphically displayed via yield-curves over time. The cumulative taxa number was described using a linear model (with a log-scaled time period). This model was then used to predict potential discoveries based on a continuation of such Biodiversity Days 50 or 300 times in different locations within the region's river network (predictions were made for 50 and 300 additional Biodiversity Days). Despite the lack of temporal replicates for each site, these predicted data can be used to roughly estimate the potential for new discoveries of aquatic invertebrates in South Tyrol.

Autecological data (saprobic classifications) was retrieved from www.freshwaterecology.info (SchmidtKloiber and Hering, 2015), the database for European freshwater fauna. EPT (Ephemeroptera-Plecoptera-Trichoptera) taxa were used for the general evaluation of the ecological status, since these groups had sufficient autecological information.

Graphics were produced using QGIS (https://qgis.org/ en/site/) and ggplot2 (Wickham, 2016) in R (R Core Team, 2018).

\section{RESULTS}

In total, 334 different aquatic invertebrate taxa (Tab. S2) were identified in all investigated sites and years. Over the whole study period (from 2001 to 2017) and across all surveyed sites, the most diverse group of aquatic animals was the dipteran family Chironomidae (non-biting midges), contributing to the total taxa pool with $23.7 \%$ (=79 taxa), followed by caddis flies (Trichoptera, 18.3\%, 61 taxa), other dipteran taxa (15.0\%, 50 taxa), mayflies (Ephemeroptera, 9.0\%, 30 taxa), stoneflies (Plecoptera, 8.1\%, 27 taxa), and oligochaetes (Oligochaeta, 7.2\%, 24 taxa). The contribution of all other groups such as beetles (Coleoptera), water mites (Hydrachnida), dragonflies and damselflies (Odonata), snails (Gastropoda), true bugs (Heteroptera), leeches (Hirudinea), bivalves (Bivalvia), flatworms (Turbellaria), megalopterans (Megaloptera), crustaceans (Crustaceae), nematodes (Nematoda), and horsehair worms (Nematomorpha), was low with a joint contribution of 18.9\% (63 taxa) to the total taxa pool (Fig. 2).

Over the duration of this study, Chironomidae
(Diptera) contributed the most to the increase of total invertebrate taxa (Fig. 2). The relative contribution of each family and group to the known taxa-pool, however, varied from site to site. During the first Biodiversity Day in 2001, most of the identified taxa belonged to Trichoptera, Plecoptera and Ephemeroptera (EPT, 68.1\%, 32 taxa, Fig. 2). The year after, discoveries of many Trichoptera taxa raised their relative contribution to the total taxa pool to $30.7 \%$ and remained the best-known order, until the biodiversity day of 2007. Thereafter, the Chironomidae dominated the pool of known taxa in South Tyrol (ranging between 22.4 and $24.5 \%$, Fig. 2B) and the proportion of
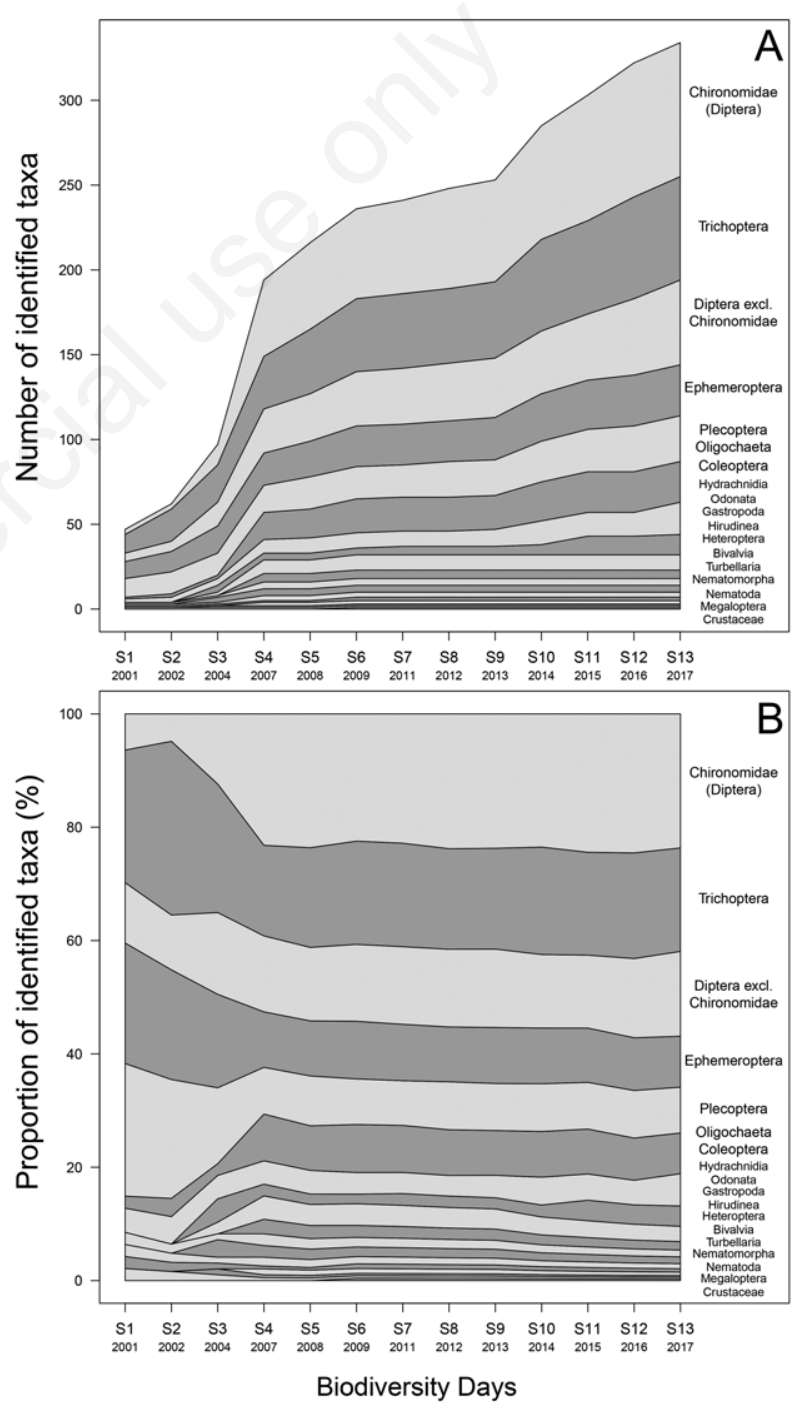

Fig. 2. Cumulative absolute (above) and relative (below) numbers of identified taxa and affiliations to taxonomic groups (family or order) over time during the study period (2001-2017). Only taxa that were newly recorded each year were added to this cumulative list. Displayed $\mathrm{x}$-axis positions indicate sites and years of Biodiversity Days. 
all taxonomic groups remained constant from then on. Next to the groups with many known taxa $(\geq 10)$ such as Chironomidae and EPT, only few taxa are known for other groups such as Crustaceae (1), Megaloptera (1), Turbellaria (2), Nematomorpha (2), Nematoda (2), Bivalvia (3), Heteroptera (4), Hirudinea (4), or Gastropoda (5, Fig. 3).

Comparing the communities from different habitat types revealed that the composition of invertebrate assemblages differed significantly between lentic and lotic habitats with the category habitat type explaining $19.4 \%$ $(\mathrm{p}<0.001)$ of the variation between sites. The composition in all sites was also weakly related to geographic position (partial $\mathrm{R}^{2}=0.07, \mathrm{p}=0.053$ ), while altitude had lower explanatory power (partial $\mathrm{R}^{2}=0.04, \mathrm{p}>0.05$ ). All three (constrained) RDA-axes explained $25.6 \%$ of the variation between the composition at different sites (Fig. 3A). Also, the saprobic composition differed between sites and was significantly related to the longitudinal distribution of the characterized communities, with the dominance of xenosaprobic and oligosaprobic taxa being highest in the western sites (Fig. S1), while no associations have been found with the altitudinal or latitudinal distribution of the sites ( $p>0.05$ ). Compared to the lentic habitats, we found riverine communities having more than twice as many taxa (Fig. 3B). Within the lentic sites, however, particularly many taxa have been identified in the pond at site S4 (Fig. 3B). In contrast to other Biodiversity Days, however, the standing habitat at site $\mathrm{S} 4$ was sampled much more intensively (more micro-habitats were sampled).

Before the first Biodiversity days, 1373 taxa of 19 orders have been registered in this region (South Tyrol). All taxa recorded during Biodiversity Days added to the total taxa pool of the region by 167 new taxa (an increase of $13 \%$, Fig. 4A), whereby the affiliation of new records to different orders were similar to the already known relative community composition (i.e., mostly diptera taxa (64), then trichoptera (25), ephemeroptera (16), oligochaeta (13), etc., Fig. 4B). The cumulative taxa list that resulted from biodiversity days shows the same hierarchy of dominant orders (Fig. S2).

The known species inventory increased with each additional Biodiversity Day and this increase was quantifiable using a logarithmic regression model $\left(\mathrm{R}^{2}=0.94\right.$, Fig.

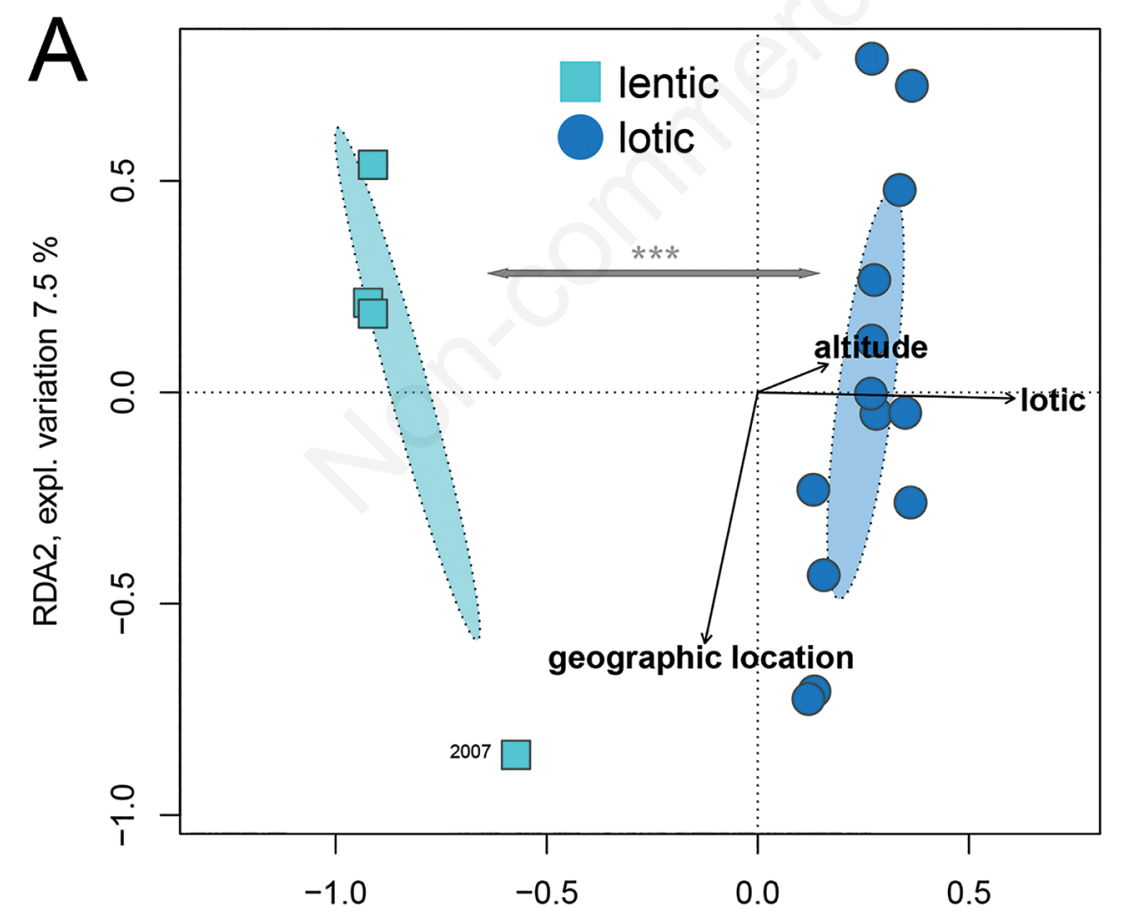

RDA1, expl. variation $13.1 \%$

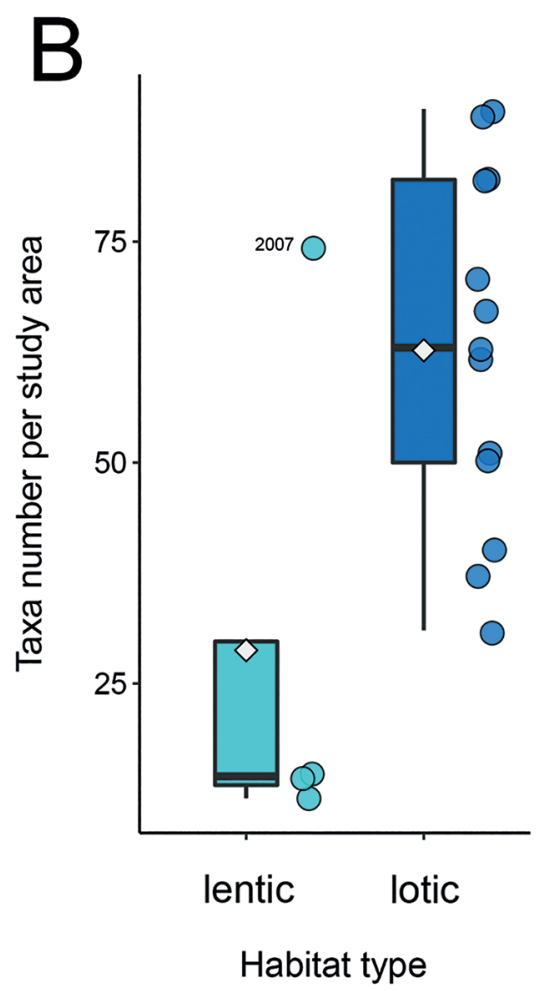

Fig. 3. Community composition in lentic and lotic habitats: A) projection of invertebrate communities and explanatory environmental variables into the 2-dimensional RDA (redundancy analysis) space; the significance of habitat type (tested using PERMANOVA) is indicated $(* * * p<0.001)$, other variables were not significantly related to community structure; Ellipses are $95 \%$ confidence intervals for communities per habitat group (lotic and lentic). B) comparison of taxa numbers in all sites grouped by habitat type; lentic, stagnant; lotic, riverine. 
$5 a)$. The same model did not reach saturation when predicting future Biodiversity Days (e.g., $\mathrm{n}=50$, Fig. 5), meaning that the known taxa inventory is predicted to continue increasing for the next decades.

\section{DISCUSSION}

This work demonstrates that each of the thirteen surveys in form of biodiversity days in the study region contributed to the understanding of the species pool in this Alpine region. Particularly, freshwater populations are experiencing drastic declines (decrease by $83 \%$ since 1970 ; WWF 2018), which is why this first identification and estimation of the regional species is very valuable for future biodiversity assessments in that region (e.g., Biodiversity Monitoring, https://biodiversity.eurac.edu). Covering a wide variety of habitats and sub-catchments, the presented surveys thus estimated not only the regional species inventory, but also identified the dominant groups in watersheds of the southern Alps.

\section{Benefits and limits of Biodiversity Days to record regional biodiversity}

Several surveys of local biodiversity have been carried out in various South Tyrolean waters (Furse et al., 2006; Sambugar et al., 2006; Lencioni et al., 2011; Scotti et al., 2019b), but the Biodiversity Days conducted over the re-

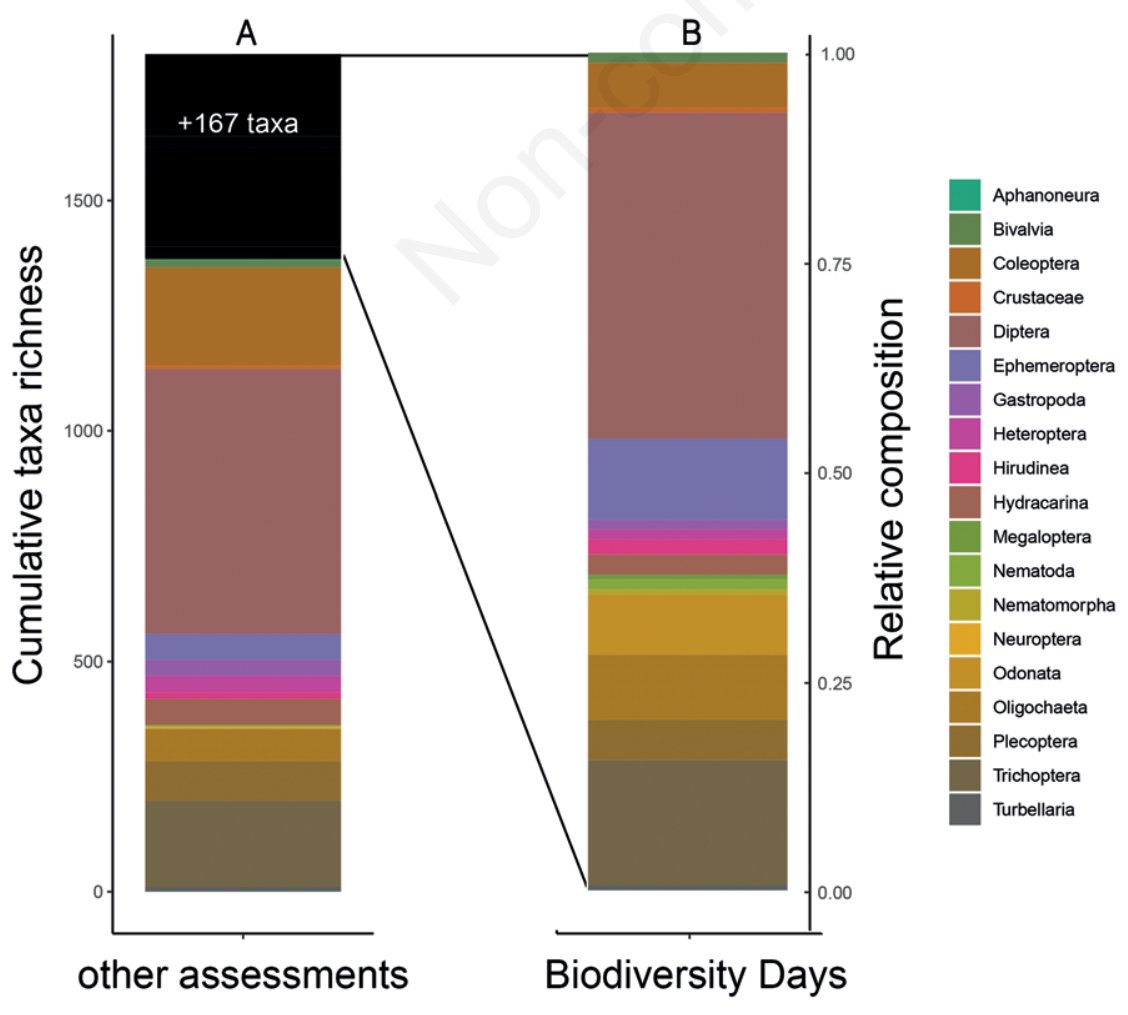

gion led to an increased knowledge about aquatic taxa forming benthic communities in different types and habitats of Alpine freshwaters. All assessments in different areas distributed across the study region's river network revealed an inventory of 334 different aquatic invertebrate taxa, with most of them belonging to the family Chironomidae (79 taxa) and the order Trichoptera (61 taxa), which is in line with other Alpine river communities (Füreder et al., 2017; Niedrist et al., 2017; Scotti et al., 2019a) and the ranking within the currently known species inventory of the European Alps (www.freshwaterecology.info, Schmidt-Kloiber and Hering, 2015). Besides the importance of the habitat type (standing vs. running water, partial $\mathrm{R}^{2}=0.19$, $\mathrm{p}<0.001$, Fig. $3 \mathrm{~A}$ ), the composition of the communities was also weakly related to the geographical location (relationship with longitude but not latitude, partial $\mathrm{R}^{2}=0.04, \mathrm{p}=0.053$, Fig. $3 \mathrm{~A}$ ). Despite the demonstrated general relationship between the composition of invertebrate communities and altitude (Jacobsen et al., 1997; Jacobsen, 2003), that was not evident in this dataset. We suppose that this is due to the limitation of the dataset presence/absence data only. The functional composition of all communities (saprobic composition) confirmed a longitudinal gradient of differences between habitats.

Compared to previous assessments and gained taxa inventory for the same region, these Biodiversity Days revealed 167 additional taxa from multiple taxonomic groups, which have been undiscovered until then. This in-
Fig. 4. Diversity of taxonomic groups in Alpine waters and contribution of Biodiversity Days: A) all taxa known from previous assessments in waters in the same region including newly detected taxa at Biodiversity Days. B) relative composition of these newly detected taxa. All taxa recorded during Biodiversity Days added to the total taxa pool of all previously registered taxa in this region by 167 taxa $(+13 \%)$. 
dicated that such Biodiversity Days contribute significantly to the knowledge of aquatic taxa in this region and to Biodiversity research in general. Over time, a different number of experts, specialized in different taxonomic groups, were involved in the studies, leading to a timedependent increase of known group-specific taxa. Although keeping the sampling effort comparable from site to site, we assume that the varying number of new records resulted from a different coverage of present microhabitats and/or taxonomic groups. During the entire study period, most taxa were identified within the groups Chironomidae, Trichoptera, other Diptera, Ephemeroptera, Plecoptera, and Oligochaeta ( $>80 \%$ of all known taxa). Although the possible taxonomic differentiation within encountered families or orders can be different or was done differently, this accumulated taxa inventory and the ranking of species groups correspond to that of the entire ecoregion 'European Alps' (SchmidtKloiber and Hering, 2015). Less taxa were identified for the groups Crustaceae, Megaloptera, Turbellaria, Nematoda, Nematomorpha, Bivalvia, Heteroptera, Hirudinea, Gastropoda, or Odonata. However, considerably more species of these neglected groups might be present in South Tyrolean waters, as indicated by online databases (Schmidt-Kloiber and Hering, 2015). Therefore, experts in these taxonomic groups are encouraged to participate in future Biodiversity Days to identify and record the various taxa within these invertebrate orders.

The list of identified taxa from the first three biodiversity days indicates an underrepresentation of usually dominant invertebrate orders or families in comparable waters or the cumulative taxa inventory of all studied sites (e.g., Chironomidae, see Fig. 2A). The morphological identification of the non-biting midges to species or species-group levels is justifiably considered difficult (Peckarsky et al., 1990; Oh et al., 2014), and chironomids are often not identified beyond family or subfamily also due to its time consumption. However, such procedure could hide important information or patterns of biodiversity (Peckarsky et al., 1990). Considering the high species diversity of Chironomidae in Alpine regions (SchmidtKloiber and Hering, 2015) and the constant dominance in taxa richness in all consecutively sampled sites (from 2008 to 2017), we assume that taxonomic groups were resolved differently over the duration of this study.

In 2007, the Biodiversity Day was carried out as part of a research project at the same site, resulting in much more sampled micro-habitats without the possibility to retrace all registered taxa. Such more intense sampling is likely responsible for the strong increase of known taxa in that year (Fig. 2A).

Surveys of aquatic invertebrates that are mandatory for

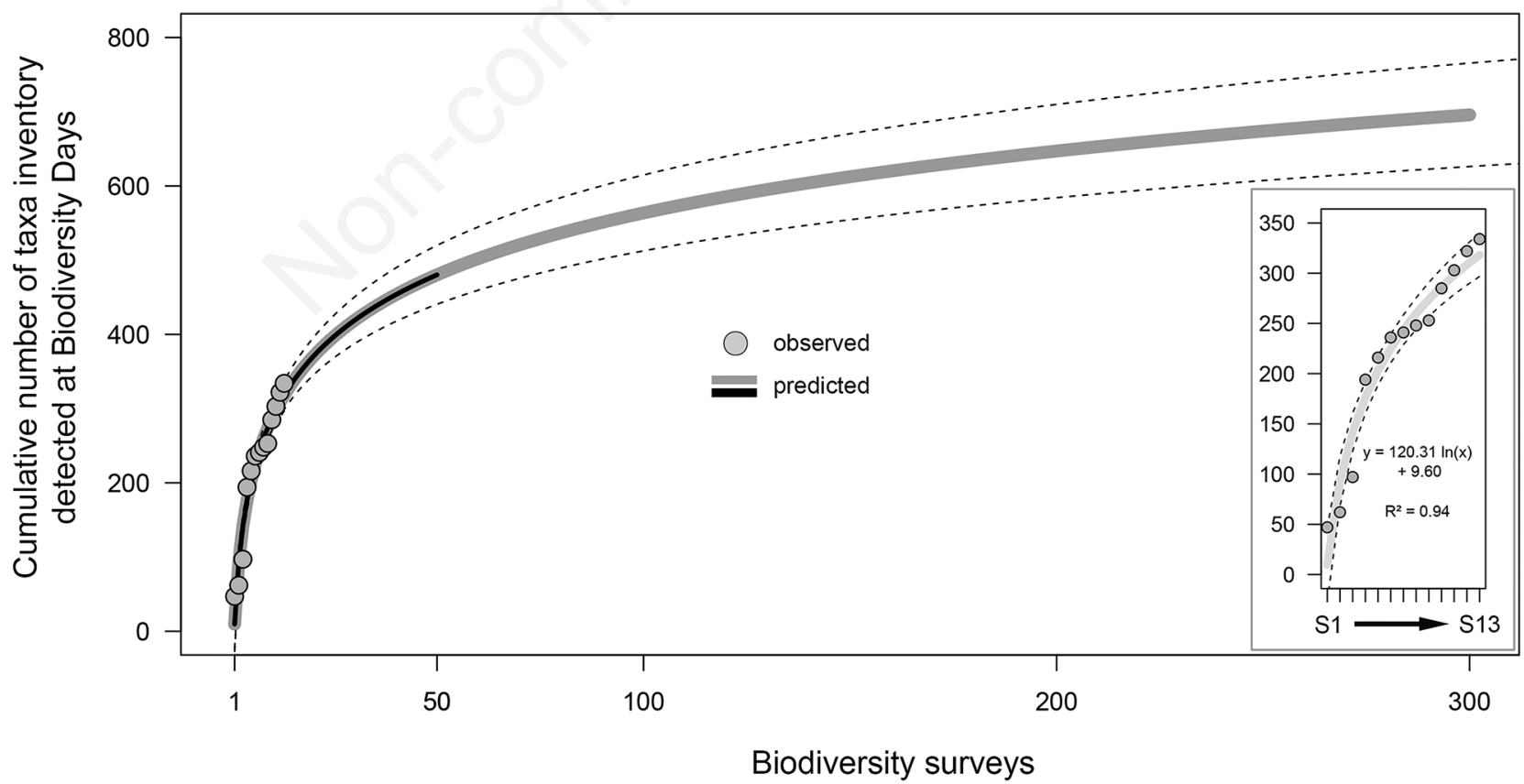

Fig. 5. Predicted increase of known aquatic taxa depending on the number of Biodiversity Days ("biodiversity surveys") based on the observed increase of the cumulative taxa numbers during the 13 Biodiversity days. The relationship is described with the (logarithmic) model and an estimation of its goodness $\left(\mathrm{R}^{2}\right)$. Different colors indicate models based on different numbers of Biodiversity Days: black, 50; dark grey, 300. Dashed lines delineate the $95 \%$ confidence interval of observed and predicted taxa numbers. 
the Water Framework Directive in waters of the same region are certainly biased, as the focus is on few larger water bodies (Bo et al., 2016), while small rivers or ponds are ignored. Thus, the taxa richness of South Tyrolean freshwaters could have been underestimated so far, analogous to other regions and rare taxonomic groups (Gessner and Van Ryckegem, 2003; Shearer et al., 2007; Kuzmina et al., 2018). However, this summary of Biodiversity Days demonstrates that voluntary efforts can contribute to a first estimation of the aquatic invertebrate richness of a region in recording taxa whose occurrence was unknown until then. Based on the existing data from past Biodiversity Days and on the increase of known taxa in that region, we conclude that Biodiversity Days will continue contributing to the discovery of aquatic taxa in the next decades. Predicting the entire taxa inventory of this region is avoided and should in any case be considered with caution, since a) the surveys focused on the most species-rich animal groups, leading to increased numbers of new taxa over time, and b) only natural habitats have been examined so far, neglecting less known water types such as urban waters, morphologically modified streams, reservoirs, ponds, eutrophic drainage ditches, etc., with their diverse communities (e.g., in urban ponds; Hill et al., 2018). Given that Alpine waters with distinct environmental conditions harbor different communities (Niedrist and Füreder, 2016), we expect that monitoring such non-natural habitats will reveal taxa that are not present in natural waters.

\section{CONCLUSIONS}

Given the contemporary rapid changes in Alpine areas (Hock et al., 2019) and warming (Niedrist and Füreder, 2021) or pollution (e.g., secondary salinization; Niedrist et al., 2021) of Alpine rivers with the background of drastic declines of freshwater populations worldwide (WWF, 2018), monitoring of regional biodiversity is essential to understand future situations (Krug et al., 2017), but also for adapting and prioritizing conservation measures. This work provides not only a basis for the planned biodiversity monitoring in that northern Italian province (see https://biodiversity.eurac.edu), but also information for nature education (regional and local species inventory used for nature tours, exhibitions, on-site information boards, etc.), and for evaluations of regional and site-specific resistance of freshwater communities for expected changes of habitat conditions. Further, this summary of data gained in Biodiversity Days demonstrates that such surveys can contribute to Biodiversity research, and thereby contribute to the regional management of natural areas (Miller-Rushing et al., 2012). This study demonstrates that Biodiversity Days represent a simple, cost effective addition for monitoring species diversity on regional scales.

\section{ACKNOWLEDGEMENTS}

We thank the Naturmuseum Südtirol for the annual organization of the Biodiversity Days. Special thanks go to the participating experts of different aquatic animal groups, namely Thomas Kiebacher, Nicole Magnani, Alexandra Mätzler, Christopher Robinson, Verena Schwitzer, and Bertha Thaler. We also thank the Biological Laboratory of the Environmental Agency of South Tyrol for the supply of personnel and material. Georg H. Niedrist was a postdoctoral fellow of the University of Innsbruck ("Graduiertenstipendium - Wasser in Gebirgsräumen"). The Institute for Alpine Environment, Eurac Research, and particularly Veronika Fontana is acknowledged for the organization of the Science Week 2016 in Matsch Valley.

\section{REFERENCES}

Abell R, Thieme ML, Revenga C, Bryer M, Kottelat M, Bogutskaya N, et al., 2008. Freshwater ecoregions of the world: A new map of biogeographic units for freshwater biodiversity conservation. Bioscience 58:403-414.

Alber R, Niedrist GH, Mätzler A, Lösch B, 2015. [Makrozoobenthos (wirbellose Flussohlenbewohner)]. In: [Tag der Artenvielfalt 2014 in St. Felix (Gemeinde Unsere Liebe Frau im Walde - St. Felix, Südtirol, Italien)].[in German]. Gredleriana 15:158-161.

Bauernfeind E, Humpesch UH, 2001. [Die Eintagsfliegen Zentraleuropas (Insecta: Ephemeroptera): Bestimmung Und Ökologie].[in German] Verlag des Naturhistorischen Museums, Wien: 239 pp.

Biggs J, Fumetti S von, Kelly-Quinn M, 2017. The importance of small waterbodies for biodiversity and ecosystem services: implications for policy makers. Hydrobiologia 793:3-39.

Bo T, Doretto A, Laini A, Bona F, Fenoglio S, 2016. Biomonitoring with macroinvertebrate communities in Italy: What happened to our past and what is the future? J. Limnol. 76:1584

Braun LN, Weber M, Schulz M, 2000. Consequences of climate change for runoff from Alpine regions. Ann. Glaciol. 31:19-25.

Brown LE, Dickson NE, Carrivick JL, Füreder L, 2015. Alpine river ecosystem response to glacial and anthropogenic flow pulses. Freshw. Sci. 34:1201-1215.

Cardinale BJ, 2011. Biodiversity improves water quality through niche partitioning. Nature 472:86-89.

Cardinale BJ, Duffy JE, Gonzalez A, Hooper DU, Perrings C, Venail P, et al., 2012. Biodiversity loss and its impact on humanity. Nature 486:59-67.

Ceballos G, Ehrlich PR, Barnosky AD, Garcia A, Pringle RM, Palmer TM, 2015. Accelerated modern human-induced species losses: Entering the sixth mass extinction. Sci. Adv. 1:e1400253-e1400253.

Collen B, Whitton F, Dyer EE, Baillie JEM, Cumberlidge N, Darwall WRT, Pollock C, Richman NI, Soulsby A-M, Böhm M, 2014. Global patterns of freshwater species diversity, 
threat and endemism. Glob. Ecol. Biogeogr. 23:40-51.

Davies BR, Biggs J, Williams PJ, Lee JT, Thompson S, 2008. A comparison of the catchment sizes of rivers, streams, ponds, ditches and lakes: implications for protecting aquatic biodiversity in an agricultural landscape. Hydrobiologia 597:7-17.

Duncan C, Thompson JR, Pettorelli N, 2015. The quest for a mechanistic understanding of biodiversity-ecosystem services relationships. Proc. Biol. Sci. 282:20151348.

Elmqvist T, Folke C, Nyström M, Peterson G, Bengtsson J, Walker B, Norberg J, 2003. Response diversity, ecosystem change, and resilience. Front. Ecol. Environ. 1:488-494.

Füreder L, 2012. Freshwater ecology: Melting biodiversity. Nat. Clim. Chang. 2:318-319.

Füreder L, Niedrist GH, Schütz SA, 2017. Monitoring Alpine rivers: recent progress and future challenges. 6th Symp. Res. Prot. Areas 163-167.

Furse M, Hering D, Moog O, Verdonschot P, Johnson RK, Brabec K, et al., 2006. The STAR project: context, objectives and approaches. Hydrobiologia 566:3-29.

García FC, Bestion E, Warfield R, Yvon-Durochera G, 2018. Changes in temperature alter the relationship between biodiversity and ecosystem functioning. Proc. Natl. Acad. Sci. USA 115:10989-10994.

Gessner MO, Ryckegem G Van, 2003. Water fungi as decomposers in freshwater ecosystems. In: Encyclopedia of Environmental Microbiology. Hoboken, John Wiley \& Sons.

Giulivo M, Stella E, Capri E, Esnaola A, López de Alda M, Diaz-Cruz S, Mandaric L, Muñoz I, Bellin A, 2019. Assessing the effects of hydrological and chemical stressors on macroinvertebrate community in an Alpine river: The Adige River as a case study. River Res. Appl. 35:78-87.

Haase P, Hering D, Jähnig SC, Lorenz AW, Sundermann A, 2013. The impact of hydromorphological restoration on river ecological status: A comparison of fish, benthic invertebrates, and macrophytes. Hydrobiologia 704:475-488.

Hill MJ, Biggs J, Thornhill I, Briers RA, Ledger M, Gledhill DG, Wood PJ, Hassall C, 2018. Community heterogeneity of aquatic macroinvertebrates in urban ponds at a multi-city scale. Landsc. Ecol. 33:389-405.

Hock R, Rasul G, Adler C, Cáceres B, Gruber S, Hirabayashi Y, et al., 2019. High Mountain Areas, p. 72. In: Pörtner H-O, DC Roberts, V Masson-Delmotte, P Zhai, M Tignor, E Poloczanska, et al. (eds.), IPCC Special Report on the Ocean and Cryosphere in a Changing Climate, Geneva, Switzerland: IPCC.

Hutchinson GE, 1957. Concluding Remarks. Cold Spring Harb. Symp. Quant. Biol. 22:415-527.

Jacobsen D, 2003. Altitudinal changes in diversity of macroinvertebrates from small streams in the Ecuadorian Andes. Arch. fur Hydrobiol. 158:145-167.

Jacobsen D, Schultz R, Encalada A, 1997. Structure and diversity of stream invertebrate assemblages: the influence of temperature with altitude and latitude. Freshwater Biol. 38:247-261.

Jacobsen JB, Boiesen JH, Thorsen BJ, Strange N, 2008. What's in a name? The use of quantitative measures versus 'Iconised' species when valuing biodiversity. Environ. Resour. Econ. 39:247-263.

Janecek BFR, 1998. [Fauna Aquatica Austriaca -Taxonomie und Ökologie aquatischer wirbelloser Organismen (Teil V)].[in
German]. Universität für Bodenkultur, Abt. Hydrobiologie (Ed.), Wien: 1-128.

Kobori H, Dickinson JL, Washitani I, Sakurai R, Amano T, Komatsu N, et al, 2016. Citizen science: a new approach to advance ecology, education, and conservation. Ecol. Res. 31:1-19.

Krug CB, Schaepman ME, Shannon LJ, Cavender-Bares J, Cheung W, McIntyre PB, et al., 2017. Observations, indicators and scenarios of biodiversity and ecosystem services change - a framework to support policy and decision-making. Curr. Opin. Environ. Sustain. 29:198-206.

Kuzmina ML, Braukmann TWA, Zakharov EV, 2018. Finding the pond through the weeds: eDNA reveals underestimated diversity of pondweeds. Appl. Plant Sci. 6:e01155.

Lencioni V, 2018. Glacial influence and stream macroinvertebrate biodiversity under climate change: Lessons from the Southern Alps. Sci. Total Environ. 622-623:563-575.

Lencioni V, Marziali L, Rossaro B, 2011. Diversity and distribution of chironomids (Diptera, Chironomidae) in pristine Alpine and pre-Alpine springs (Northern Italy). J. Limnol. 70:106.

Lösch B, 2008. [Makrozoobenthos und Diatomeen im Schlerngebiet (Südtirol)].[in German]. Gredleriana 8:175-188.

Lösch B, 2013. [Wirbellose Flusssohlenbewohner (Makrozoobenthos). In: Tag der Artenvielfalt 2012 in Ridnaun (Gemeinde Ratschings, Südtirol, Italien)].[in German]. Gredleriana 12:162-163.

Lösch B, 2014.[ Wirbellose Flussohlenbewohner (Makrozoobenthos). In: Tag der Artenvielfalt 2013 auf den Armentara-Wiesen (Gemeinde Wengen, Südtirol, Italien)].[in German]. Gredleriana 13:304-305.

Lösch B, Alber R, 2009. [Makrozoobenthos (wirbellose Flussohlenbewohner). In: GEO-Tag der Artenvielfalt 2008 am Reschenpass (Gemeinde Graun im Vinschgau, Südtirol, Italien)].[in German]. Gredleriana 9:307-309.

Lösch B, Alber R, Robinson CT, 2012. [Makrozoobenthos (wirbellose Flussohlenbewohner). In: Tag der Artenvielfalt 2011 im Münstertal in den Gemeinden Taufers (I) und Val Müstair (CH)].[in German]. Gredleriana 12:320-322.

Lösch B, Niedrist GH, Alber R, 2016. [Makrozoobenthos (wirbellose Flussohlenbewohner). In: Tag der Artenvielfalt 2015 in Weißenbach (Gemeinde Sarntal, Südtirol, Italien)].[in German]. Gredleriana 16:202-204.

Lubini V, Knispel S, Vincon G, 2012. Die Steinfliegen der Schweiz: Bestimmung und Verbreitung Fauna Helvetica. CSCF, SEG, Neuchatel.

Macadam CR, Stockan J, 2015. More than just fish food: ecosystem services provided by freshwater insects. Ecol. Entomol. 40:113-123.

McKinney ML, Lockwood JL, 1999. Biotic homogenization: a few winners replacing many losers in the next mass extinction. Trends Ecol. Evol. 14:450-453.

Miller-Rushing A, Primack R, Bonney R, 2012. The history of public participation in ecological research. Front. Ecol. Environ. 10:285-290.

Muhar S, Muhar A, Siegrist D, Egger G, 2019. Rivers of the Alps. Haupt Verlag, Bern: 512 pp.

Naeem S, Thompson LJ, Lawler SP, Lawton JH, Woodfin RM, 1994. Declining biodiversity can alter the performance of ecosystems. Nature 368:734-737. 
Niedrist GH, Alber R, Rauch H, Vorhauser S, Kiebacher T, Scotti A, Bottarin R, 2017. Aquatic invertebrates along the progression of glacial and non-glacial streams in Matsch Valley (South Tyrol, Italy). Gredleriana 17:129-140.

Niedrist GH, Cañedo-Argüelles M, Cauvy-Fraunié S, 2021. Salinization of Alpine rivers during winter months. Environ. Sci. Pollut. Res. 28:7295-7306.

Niedrist GH, Füreder L, 2016. Towards a definition of environmental niches in alpine streams by employing chironomid species preferences. Hydrobiologia 781:143-160.

Niedrist GH, Füreder L, 2017. Trophic ecology of alpine stream invertebrates: Current status and future research needs. Freshw. Sci. 36:466-478.

Niedrist GH, Füreder L, 2021. Real-time warming of Alpine streams: (re)defining invertebrates' temperature preferences. River Res. Appl. 37:283-293.

Noss RF, 1990. Indicators for monitoring biodiversity: A hierarchical approach. Conserv. Biol. 4:355-364.

Ofenböck T, Moog O, Hartmann A, Stubauer I, 2010. [Leitfaden zur Erhebung der Biologischen Qualitätselemente Teil A2 Makrozoobenthos].[in German]. Bundesministerium für Land- und Forstwirtschaft, Wien: $226 \mathrm{pp}$.

Oh JT, Epler JH, Bentivegna CS, 2014. A rapid method of species identification of wild chironomids (Diptera: Chironomidae) via electrophoresis of hemoglobin proteins in sodium dodecyl sulfate polyacrylamide gel (SDS-PAGE). Bull. Entomol. Res. 104:639-651.

Oksanen J, Blanchet FG, Friendly M, Kindt R, Legendre P, Mcglinn D, Minchin PR, O'Hara RB, Simpson GL, Solymos P, HMH Stevens, Szoecs E, Wagner H, 2017. vegan: Community Ecology Package.https://cran.r-project.org

Olden JD, Poff NLR, Douglas MR, Douglas ME, Fausch KD, 2004. Ecological and evolutionary consequences of biotic homogenization. Trends Ecol. Evol. 19:18-24.

Oliver TH, Heard MS, Isaac NJB, Roy DB, Procter D, Eigenbrod F, Freckleton R, Hector A, Orme CDL, Petchey OL, Proença V, Raffaelli D, et al., 2015. Biodiversity and Resilience of ecosystem functions. Trends Ecol. Evol. 30:673-684.

Peckarsky BL, Fraissinet MA, Penton MA, Conklin DJ, 1990. Freshwater macroinvertebrates of Northeastern North America. Cornell University Press, Ithaca, New York: 442 pp.

Petchey OL, 2003. Integrating methods that investigate how complementarity influences ecosystem functioning. Oikos 101:323-330.

Peterson G, Allen CR, Holling CS, 1998. Ecological resilience, biodiversity, and scale. Ecosystems 1:6-18.

Prather CM, Pelini SL, Laws A, Rivest E, Woltz M, Bloch CP, Toro I Del, Ho C-K, Kominoski J, Newbold TAS, Parsons S, Joern A, 2013. Invertebrates, ecosystem services and climate change. Biol. Rev. 88:327-348.

R Core Team, 2018. R: A Language and Environment for Statistical Computing. R Foundation for Statistical Computing, Vienna Austria. $\mathrm{R}$ Foundation for Statistical Computing, Vienna.
Rossaro B, Lencioni V, 2015. A key to larvae of species belonging to the genus Diamesa from Alps and Apennines (Italy). Eur. J. Environ. Sci. 5:62-79.

Rossaro B, Lencioni V, Boggero A, Marziali L, 2006. Chironomids from Southern Alpine running waters: Ecology, biogeography. Hydrobiologia 562:231-246.

Sala OE, Chapin FSC 3rd, Armesto JJ, Berlow E, Bloomfield J, Dirzo R, Huber-Sanwald E, Huenneke LF, Jackson RB, Kinzig A, Leemans R, Lodge DM, et al., 2000. Global biodiversity scenarios for the year 2100. Science 287:1770-4.

Sambugar B, Dessì G, Sapelza A, Stenico A, Thaler B, Veneri A, 2006. [Südtiroler Quellfauna].[in German]. Autonome Provinz Bozen, Bozen: 365 pp.

Schmidt-Kloiber A, Hering D, 2015. www.freshwaterecology.info - An online tool that unifies, standardises and codifies more than 20,000 European freshwater organisms and their ecological preferences. Ecol. Indic. 53:271-282.

Scotti A, Jacobsen D, Tappeiner U, Bottarin R, 2019a. Spatial and temporal variation of benthic macroinvertebrate assemblages during the glacial melt season in an Italian glacierfed stream. Hydrobiologia 827:123-139.

Scotti A, Tappeiner U, Bottarin R, 2019b. Stream benthic macroinvertebrates abundances over a 6-year monitoring period of an Italian glacier-fed stream. Biodivers. Data J. 7:33576.

Shearer CA, Descals E, Kohlmeyer B, Kohlmeyer J, Marvanová L, Padgett D, Porter D, Raja HA, Schmit JP, Thorton HA, Voglymayr H, 2007. Fungal biodiversity in aquatic habitats. Biodivers. Conserv. 16:49-67.

Strayer DL, Dudgeon D, 2010. Freshwater biodiversity conservation: recent progress and future challenges. J. N. Am. Benthol. Soc. 29:344-358.

U.S. Environmental Protection Agency, 2018. SESDPROC-508R4, Multi-Habitat Macroinvertebrate Sampling in Wadeable Freshwater Streams, Replaces SESDPROC-508-R3. Athens, Georgia: 14 pp.

Valiente-Banuet A, Aizen MA, Alcántara JM, Arroyo J, Cocucci A, Galetti M, García MB, García D, Gómez JM, Jordano P, Medel R, Navarro L, et al., 2015. Beyond species loss: the extinction of ecological interactions in a changing world. Funct. Ecol. 29:299-307.

Wallace JB, Webster JR, 1996. The role of macroinvertebrates in stream ecosystem function. Annu. Rev. Entomol. 41:115-139.

Waringer J, Graf W, 1997. [Atlas Der Österreichischen Köcherfliegenlarven Unter Einschluß Der Angrenzenden Gebiete (Ergänzungen Und Berichtigungen), p. 143-160].[in German]. Facultas Universitätsverlag, Wien:.

Wickham H, 2016. Ggplot2: Elegant Graphics for Data Analysis. Springer, New York.

WWF, 2018. Living Planet Report - 2018: Aiming Higher. Gland: 75 pp.

Zwick P, 2004. Key to the west palaearctic genera of stoneflies (Plecoptera) in the larval stage. Limnologica 34:315-348. 